\author{
Lyudmyla M. MALYARETS ${ }^{1}$ \\ Iryna P. OTENKO
}

\title{
MODELING OF EXPORT-IMPORT POTENTIAL
}

\begin{abstract}
The article deas with the process of modeling export and import potential as a sequence of transformations of cognitive, substantive, conceptual, informational, and mathematical models. It describes these models and provides recommendations for the development of each of them. It is recommended that a cognitive model of export-import potential is defined as the combination of the subject (the ability) and the object (the possibility) of its components contributing to the ability to carry out export and import operations, an opportunity to provide them a positive balance, namely to carry out effective export and import activities for the formation and reproduction of a competitive position on domestic and foreign markets. A list of the main analytical tasks of determining the export and import potential was proposed in this paper. It was given real-world multiobjective optimization model for finding optimal values of indicators of export-import potential of the enterprise.
\end{abstract}

Keywords: export import potential, cognitive model, substantial model, conceptual model, information model, mathematical model, control.

\section{INTRODUCTION}

Export-import development ensures the development of countries, regions and enterprises in modern conditions. It is through the use of this potential is the country's entry into the world economy, a high level of development of the region and the efficiency of the company. But the efficiency of export-import potential is due to the implementation of all functions that control them, so the research problem of this potential is relevant and necessary. For example, one of the need of export-import potential of Ukraine is evidenced by the following statistics: in the first half of 2019, exports of goods amounted to 24469,0 million. The United States, or of $105.2 \%$ compared with the first half of 2018, import - 28205,4 million or $108.5 \%$ (Publication of documents of the State Service of Statistics of Ukraine (2019)).

The aim of the research is justification of values and recommendations of the development of sequence models of export-import potential, which serve as the scientific basis for the management of the potential.

\footnotetext{
${ }^{1}$ Lyudmyla M. Malyarets, Professor, Head of Department of Higher Mathematics, Economic and Mathematical Methods, Simon Kuznets Kharkiv National University of Economics, Kharkiv, Ukraine, e-mail: malyarets@ukr.net. ORCID: 0000-0002-1684-9805.

2 Iryna P. Otenko, Professor, Head of Department of International Business and Economic Analysis, Simon Kuznets Kharkiv National University of Economics, Kharkiv, Ukraine, e-mail: otenkoip@gmail.com. ORCID: 0000-0001-7849-2381.
} 


\subsection{Methodology of research}

Models of export-import potential are a scientific basis for the implementation of all management functions. Hence, the prerequisites of effective management of export-import potential is the adequacy, reliability and efficiency of its models. Therefore, to carry out simulation expatria-import potential should be according to its methodology. Understanding the model of export-import potential as it is, is a formalized way, which is in the process of studying this potential substitutes, and provides new knowledge, the process modeling should be viewed as a sequence of the development of models such as: cognitive (mental picture of export-import potential), content (presentation of the cognitive model building in natural language), conceptual (formulation conceptual model the concepts and ideas of the existing theory of the potential), formal models (views of the conceptual model of the potential using the methods of mathematics or other formal languages) (Malyarets, 2014). Also, the modeling of import and export potential should take into account that there are three kinds of conceptual models: logical-semantic, structural-functional and causal ones, as well as two kinds of formal models: mathematical and information ones (Trusov, 2004). Consequently, the modeling of export-import potential involves the development of cognitive, substantive, conceptual and formal models, which are in fact stages of the modeling techniques of this potential. This understanding of the modeling provides an adequate reflection of such a complex characteristics of the object as its potential. The formation of cognitive and conceptual models of export-import potential is through the analysis of scientific and practical works of well-known specialists on the issues of potential, foreign economic activity and export-import activities such as Spiridon Pralea (2012), Minh Quang Dao (2014), Cooke, S. \& Watson, P. (2011), Stoian, M., Rialp, A. \& Rialp, J. (2012), Draghescu, F. (2015) and others. Also the theoretical foundations of the potential is reflected in the writings of such domestic and foreign scientists-economists as N. Kasyanov V., Solokha D. V., Moreva V.V., A.V. Belyakov, A. Be. Talk (2013), Pogorelov Yu. s. (2016), Zdeněk Mikoláš (2014) and others. Despite the obvious merit of these works, a significant drawback is the lack of perfect theory that would appear in a conceptual model of potential, the General trend of emphasis on one of its characteristics. The presentation about exportimport potential creates a correct idea of it as for modeling, and to manage it in practice.

\section{MODELS OF EXPORT-IMPORT POTENTIAL}

\subsection{A cognitive model}

The export and import potential is a combination of abilities and possibilities to carry out export and import operations, to provide them a positive balance, to carry out effective international business for the formation and reproduction of competitive position on domestic and foreign markets (Malyarets, 2018). It is recommended to distinguish the types of export and import potential according to the following classification criteria as level of governance (global, national, sectoral, regional), types of management (strategic, tactical, operational, situational), components (export, import), structural and functional elements (resource, technical, technological, financial, informational, managerial, organizational), form of representation in the process (formation, using, development of the potential) (Malyarets, 2017). Such a declaration about export and import potential is more correct for modelling, as well as for managing in the practice. 


\subsection{A meaningful model}

Substantial model is clear, structured expresses the cognitive representation of exportimport potential. According to the cognitive model a meaningful model of export-import potential in the structural form shown in Fig. 1.

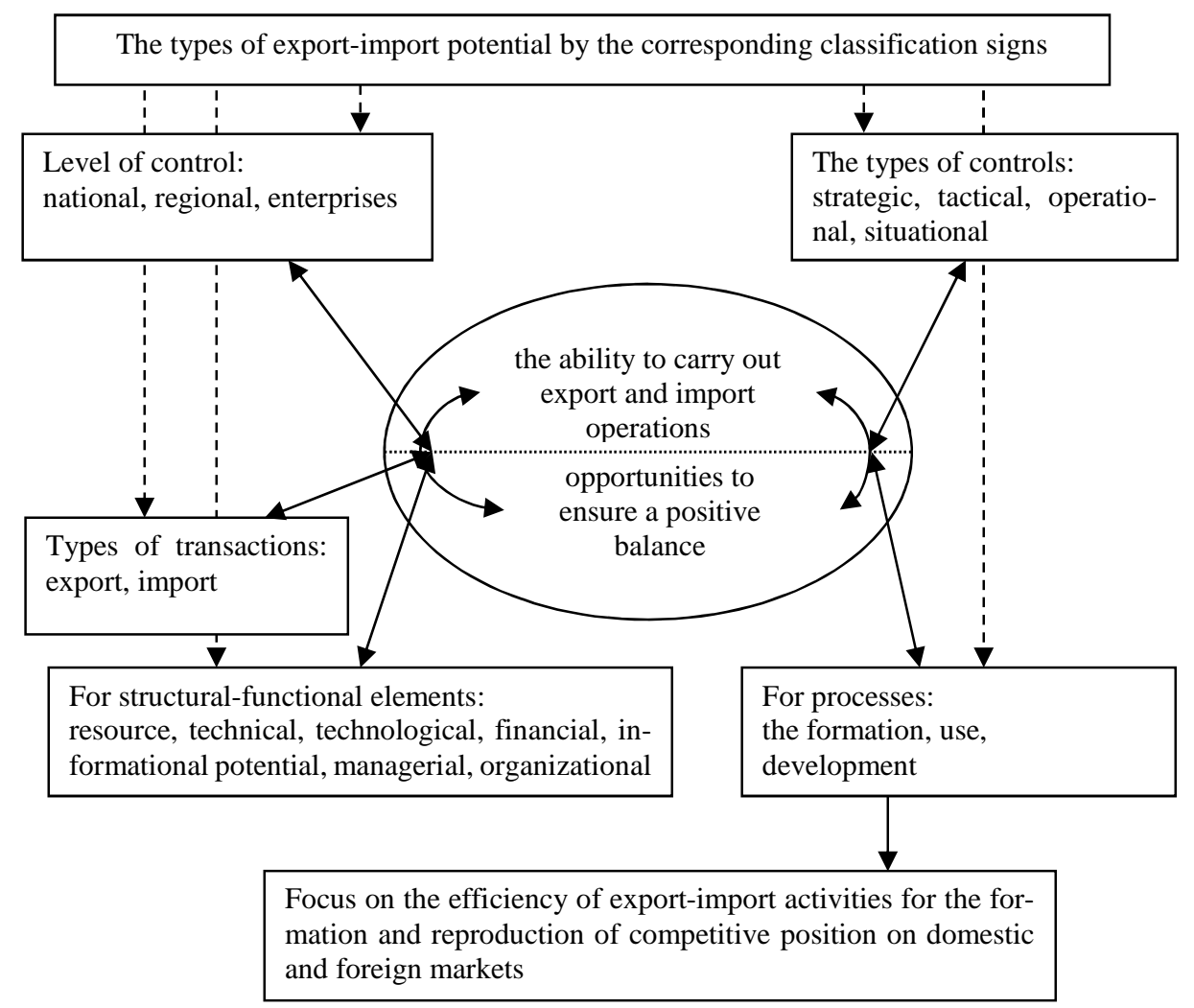

Fig. 1. A meaningful model of export-import potential

Source: own study.

\subsection{Conceptual model}

Substantial model is clear, structured expresses the cognitive representation of exportimport potential. For a meaningful model it is a conceptual model, which expressed area model in the concepts of the subject and considers its laws and regularities. Development of a conceptual model directly based on the analysis of the developments of scientists and practitioners on the theory of potential, existing concepts of potential in domestic and foreign science and practice, theory of foreign economic activity, export-import activities (Otenko, 2015). An analysis of the leading specialists in Ukraine and abroad have allowed us to build a semantic conceptual model of export-import potential of industrial enterprise (Fig. 2). 


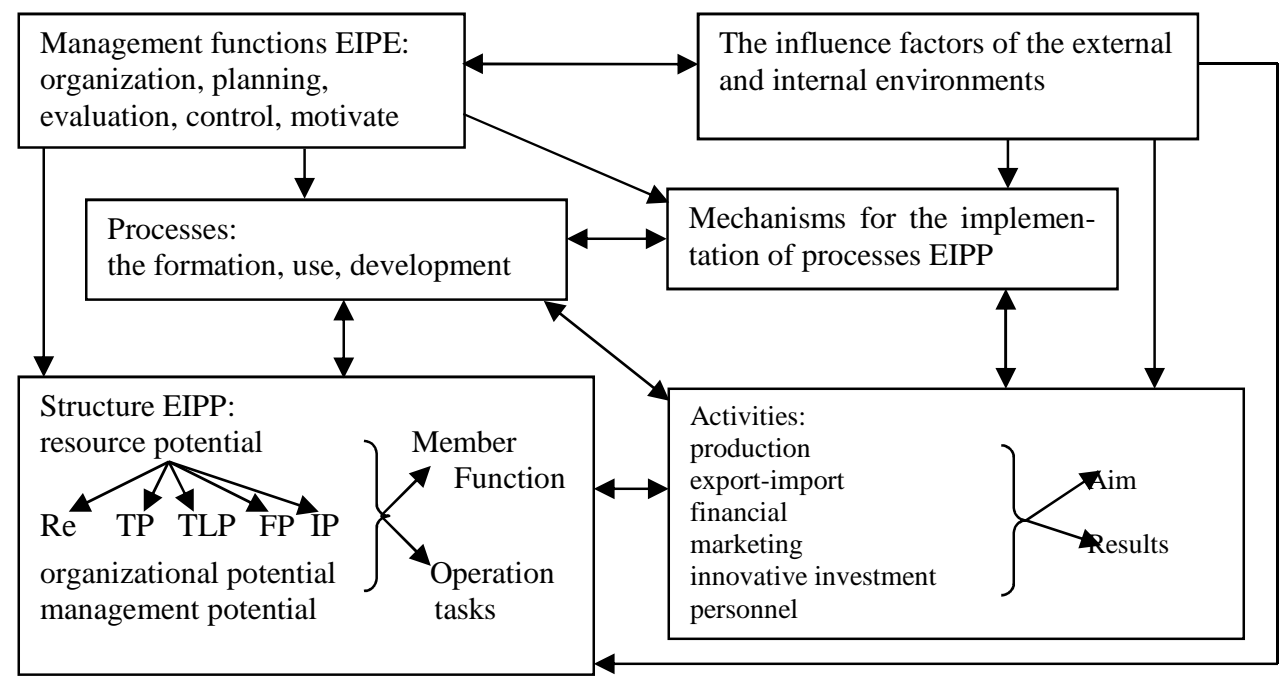

Fig. 2. Conceptual model of export-import potential of the enterprise (EIPE), where $\mathrm{Re}$ - enterprise resources (human, natural, monetary, information, means of production: fixed and current); TP - technical potential, TLP - technological potential, financial potential; FP - financial potential; IP - information potential

Source: own study.

\subsection{Information model}

In the modeling of objects in the economy is required the building information model, which is usually represented by a hierarchical system of basic signs, the values of which are measured in different scales (metric and americna) and reflected in the relevant indicators. Given the theory of the measurement of features of objects in the economy (Malyarets, 2006) and recommendations of economic analysis, the total schematic diagram of the information model of export-import potential of the enterprise for complex and basic characteristics depicted in Fig. 3. Of course the objectivity of the developed information model depends on the accuracy of the computed mathematical models in Economics. At formation of information model adhere to the following requirements: adequately reflect the substantial and the conceptual model to take into account the hierarchy, that is to contain the parameters that determine the basic, complex characteristics to take into account the multidimensionality, measured through metric and americna quantities of signs to be limited key defining indicators contain information comparable in time and space, meet the principles of statistical reporting and rely on the data of primary accounting documentation and summary information of management accounting. 


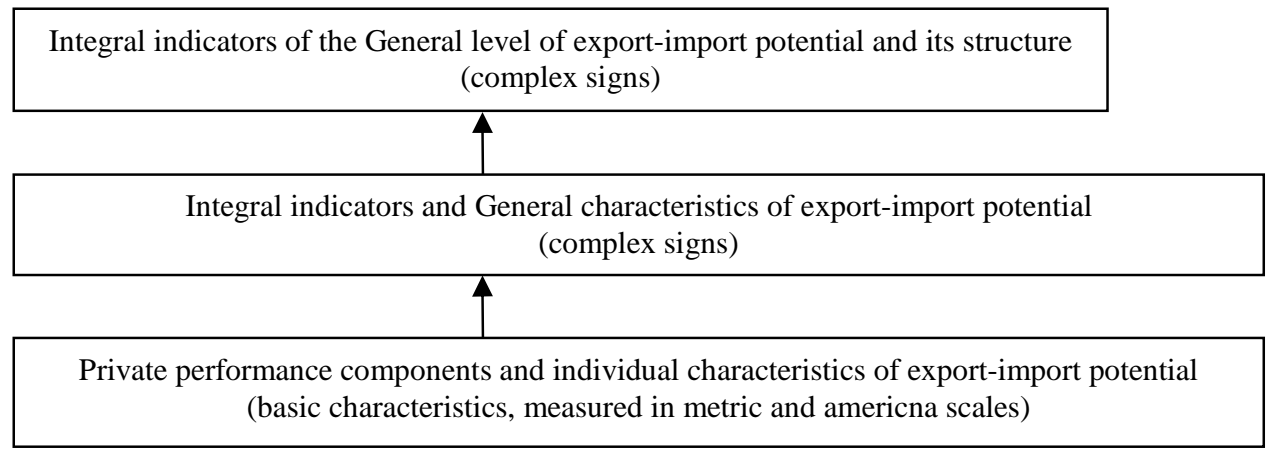

Fig. 3. A General diagram of contents of an information model for indicators export-import potential

Source: own study.

The information model of export-import potential can in general be represented with the tuple of characteristics which reflect its conceptual model, namely, in this kind of complex and elementary features: $O=\left\langle\begin{array}{l}O_{s_{s p}}, O_{s}(s k), O_{s s t}, O_{s}(m), O_{s}(p r), O_{s}(f), O_{e}(s k), \\ O_{e}(s t), O_{e}(m), O_{e}(p r), O_{e}(f)\end{array}\right\rangle$,

where $O_{s}$ - a sign of the (complex) overall level of export-import potential; $O_{s}(s k)-$ signs of (complex) components of the potential; $O_{s s t}-$ the characteristic (complex) level of structure potential; $O_{s}(m)$ - signs of (complex) mechanisms for realizing the potential; $O_{s}(p r)$ - signs of (complex) processes of potential; $O_{s}(f)$ - signs (complex) factors influencing the potential; $O_{e}(s k)$ - signs (elementary) components of the potential; $O_{e}(s t)$ - features (basic) structural elements of the potential; $O_{e}(m)-$ signs (elementary) mechanisms of realization of potential; $O_{e}(p r)$ - signs of (basic) processes of potential; $O_{e}(f)$ - signs (elementary) factors influencing the potential. For example, large industrial enterprises system of indicators export-import potential is recommended in this part of the partial indicators that reflect the status and level of development of export-import potential of the enterprise are: $x_{1}$ - the share of exports in sales; $x_{2}$ - the share of imports in the volume of sales; $x_{3}$ - the density of export enterprises in the external market; $x_{4}$ - the share of the domestic market; $x_{5}$ - the rate of change of export supplies; $x_{6}$ - the pace of change of import; $x_{7}-$ the level of product diversification of exports; $x_{8}-$ utilization of working time; $x_{9}$ - the share of employees with higher education; $x_{10}-$ the proportion of workers trained in new occupations; $x_{11}$ - the proportion of employees who improved their qualifications during the reporting period; $x_{12}$ - the turnover rate; $x_{13}$ - productivity; $x_{14}$ - the coefficient of renewal of fixed assets; $x_{15}$ - capital productivity; $x_{16}$ - the capitallabor ratio; $x_{17}-$ the ratio of own working capital; $x_{18}$ - the share of own circulating funds in the assets; $x_{19}$ - ratio of capital turnover; $x_{20}$ - the turnover ratio working capital; $x_{21}$ - the turnover ratio of inventory; $x_{22}$ - the turnover ratio of finished products; $x_{23}-$ the turnover ratio of equity capital; $x_{24}$ - the coefficient of autonomy; $x_{25}$ - the coefficient of maneuverability; $x_{26}$ - measure of financial leverage; $x_{27}$ - the security coefficient of stocks and expenses 
own funds; $x_{28}$ - the stock of material resources; $x_{29}$ - the intensity of production; $x_{30}$ - the amount of material costs; $x_{31}$ - amortization; $x_{32}$ - the cost of labor); $x_{33}$-deductions for social events; $x_{34}$ - other operating expenses; $x_{35}$ - the volume of inventories; $x_{36}$ - the volume of work in progress; $x_{37}$ - the volume of finished products. The specific indicators that reflect the use of export-import potential of the company such as: $y_{1}$ - economic efficiency of export; $y_{2}-$ the economic efficiency of the import; $y_{3}$ - the profitability of export; $y_{4}$ - the profitability of export operations; $y_{5}$ - the profitability of imports; $y_{6}$ - the profitability of imports; $y_{7}$ - gross profit margin; $y_{8}$ - operating margin; $y_{9}-$ net profit margin.

\subsection{Mathematical model}

It should be noted that the complex signs of potential mathematically modeled on the basis of elementary features that are measured in different scales and generated indicators. Based on the elementary features of the information model are calculated mathematical descriptive megamodel potential, which consists of various models that display blocks of the conceptual model. To megamodel potential includes integral indicators of the General level of development, structure, each component of the potential models for determining the factors influencing the potential of the model efficiency potential, forecasting models, multi-objective optimization models. In table. 1 lists the analytical task of determining the potential of mathematical methods, by which they are solved and the results of the decision.

Table 1. A list of the main analytical problems of determination of export-import potential

\begin{tabular}{|l|l|l|}
\hline \multicolumn{1}{|c|}{ The contents of analytical tasks } & Solution method & \multicolumn{1}{|c|}{$\begin{array}{c}\text { The result } \\
\text { of the decision }\end{array}$} \\
\hline $\begin{array}{l}\text { 1) Identify the main characteristics (basic and complex) } \\
\text { export-import potential }\end{array}$ & $\begin{array}{l}\text { Theoretic and lo- } \\
\text { gical analysis }\end{array}$ & $\begin{array}{l}\text { Principal and se- } \\
\text { condary signs }\end{array}$ \\
\hline $\begin{array}{l}\text { 2) Analysis of trends in the values of particular indicators } \\
\text { (elementary signs) }\end{array}$ & $\begin{array}{l}\text { Tools of de- } \\
\text { scriptive statistics }\end{array}$ & $\begin{array}{l}\text { Symbolic space } \\
\text { models }\end{array}$ \\
\hline $\begin{array}{l}\text { 3) Determination of General level of development of } \\
\text { export-import potential, levels of development of its } \\
\text { components and its structure (complex signs) to describe } \\
\text { this potential }\end{array}$ & $\begin{array}{l}\text { Methods of } \\
\text { building the } \\
\text { integral indicators }\end{array}$ & $\begin{array}{l}\text { Methods of } \\
\text { building the } \\
\text { integral indicators }\end{array}$ \\
\hline $\begin{array}{l}\text { 4) Determination of a causal relationship in the structure } \\
\text { of export-import potential }\end{array}$ & $\begin{array}{l}\text { Regression, } \\
\text { factor, cluster, } \\
\text { canonical analyses }\end{array}$ & $\begin{array}{l}\text { The causal } \\
\text { relationship } \\
\text { structures and } \\
\text { processes and } \\
\text { mechanisms }\end{array}$ \\
\hline $\begin{array}{l}\text { 5) Determine the optimal values of the measures of } \\
\text { implemented features and efficiency of export-import } \\
\text { potential }\end{array}$ & $\begin{array}{l}\text { Multiobjective } \\
\text { optimization } \\
\text { methods }\end{array}$ & $\begin{array}{l}\text { The optimal } \\
\text { values }\end{array}$ \\
\hline $\begin{array}{l}\text { 6) Forecasting of the values of export and import potential } \\
\text { to identify trends and diagnostics development }\end{array}$ & $\begin{array}{l}\text { Models of growth } \\
\text { curves }\end{array}$ & $\begin{array}{l}\text { The predicted } \\
\text { values of the } \\
\text { indicators }\end{array}$ \\
\hline
\end{tabular}

Source: own study.

So, mathematical megamodel of export-import potential can be represented in the logic of the separate mathematical models, as shown in Fig. 4. 
For example, when calculating the multi-objective optimizing model of export-import potential of the enterprise private criteria it is advisable to consider two criteria, namely the level of development $\left(F_{1} \rightarrow \max \right)$ and the efficiency of it $\left(F_{2} \rightarrow \max \right)$. In the process of compiling individual criteria should consider the impact of each individual factor (Malyarets, 2018). To accomplish this we paired based on appropriate levels from each factor of influence. In this many-criterial optimisation tasks as constraints, it is recommended to use intervals of values of the factors with regard to their numerical characteristics, namely the minimum, maximum values of the index and standard error. Specific criteria should take into account the dependency levels of its factors with the preset weight coefficients, which are based on the priority factors of influence.

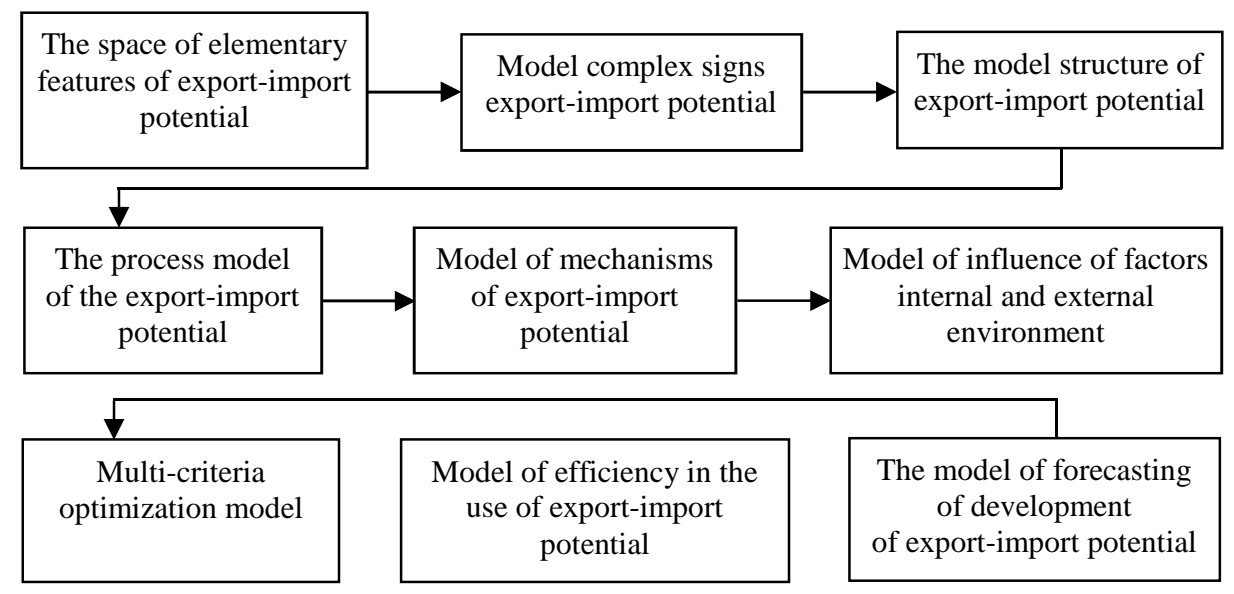

Fig. 4. The logic of development of mathematical megamodel export-import potential

Source: own study.

For example, specific criteria in multi-criteria optimzation problem of determining the optimal values of indicators of export-import potential of PJSC „Turboatom” (Kharkiv, Ukraine), built by the recommended system indicators large industrial enterprises, have the following form:

$$
\begin{aligned}
& F_{1}=0,05\left(0,0402+\frac{0,2132}{x_{1}}\right)+0,05\left(\frac{1}{-1,6312+\frac{0,5978}{x_{2}}}\right)+ \\
& +0,05 \sqrt{0,2395-2,526 E(-10) x_{3}^{2}}+ \\
& +0,05\left(\sqrt{0,0136+0,2045 x_{4}^{2}}\right)+0,05 e^{-1,224+\frac{0,4435}{x_{5}}}+0,05 \sqrt{0,2257-0,0111 x_{6}^{2}}+
\end{aligned}
$$




$$
\begin{aligned}
& +0,05 \sqrt{0,7563-\frac{0,4904}{x_{7}}}+0,0216 e^{69,0143-\frac{59,926}{x_{8}}}+ \\
& +0,0216 \sqrt{-1,1686+14,6492 x_{9}^{2}}+ \\
& +0,0216\left(\frac{1}{1,642+8,7707 x_{10}}\right)+0,0216\left(\frac{1}{1,9229+21,1762 x_{11}^{2}}\right)+ \\
& 0,0216 \sqrt{-0,0806+7,4098 x_{12}}+ \\
& +0,0216\left(\frac{1}{1,53+0,0007 x_{13}^{2}}\right)+0,0216 \sqrt{0,9677+0,2145 \ln x_{14}}+ \\
& +0,0216 \frac{1}{1,1379+\frac{3,1033}{x_{15}}}++0,0216 \sqrt{1,6014-\frac{65,1425}{x_{16}}}+ \\
& +0,0216 \frac{1}{1,5655+3,3306 x_{17}^{2}}+0,0216 \sqrt{-0,0013+2,2369 x_{18}^{2}}+ \\
& +0,0216 \frac{1}{0,675+\frac{0,696}{x_{19}}}+0,0216 \frac{1}{0,1867+\frac{3,053}{x_{20}}}+0,0216 e^{-1,325+0,2914 x_{21}^{2}}+ \\
& +0,0216 \frac{1}{1,6305+\frac{3,1689}{x_{22}}}+0,0216 \frac{1}{0,7372+\frac{0,9346}{x_{23}}}+ \\
& +0,0216 \frac{1}{-2,191+8,991 x_{24}^{2}}++0,0216 \sqrt{-0,0355+1,2489 x_{25}^{2}}+ \\
& +0,0216 \frac{1}{-0,0721+\frac{0,9514}{x_{26}}}+0,0216 \frac{1}{0,9807+5,302 x_{27}^{2}}+ \\
& +0,0216 \sqrt{0,0252+2,138 E(-7) x_{28}}+0,0216\left(0,7092-\frac{1,2359}{x_{29}}\right)+ \\
& +0,0216 \sqrt{-0,319+1,862 x_{30}^{2}}+0,0216 \frac{1}{6,017-\frac{0,1062}{x_{31}}}+ \\
& 0,0216 \frac{1}{-6,2614+17,8626 \sqrt{x_{32}}}+ \\
& +0,0216 \frac{1}{-1,8474+46,0463 x_{33}}+0,0216 \frac{1}{1,4261+\frac{0,1048}{x_{34}}}+0,0216 e^{0,0973-\frac{0,1974}{x_{35}}}+
\end{aligned}
$$




$$
\begin{aligned}
& +0,0216 \frac{1}{1,1098+\frac{0,251}{x_{36}}}+0,0216 \frac{1}{1,3902+6,3879 x_{37}} \rightarrow \max . \\
& F_{2}=0,2 \frac{1}{6,0467-3,6403 y_{1}}+0,15\left(\frac{1}{-0,3987+\frac{3,1784}{y_{2}}}\right)+0,2 \sqrt{0,1276+\frac{0,2952}{y_{3}}}+ \\
& +0,15\left(0,9465-\frac{505,31}{y_{4}}\right)+0,1\left(\frac{1}{1,3329-0,4465 \ln y_{5}}\right)+0,05\left(\frac{1}{1,0803+\frac{0,0507}{y_{6}}}\right)+ \\
& +0,05 \sqrt{0,079+2,2857 y_{7}^{2}}+0,05 e^{0,251-\frac{0,1957}{y_{8}}}+0,05\left(\frac{1}{0,8448+\frac{0,1751}{y_{9}}}\right) \rightarrow \max .
\end{aligned}
$$

Constraints are:

$0,4671 \leq x_{1} \leq 0,7213,0,1227 \leq x_{2} \leq 0,1785,10301,2738 \leq x_{3} \leq 14998,662 ;$

$0,9055 \leq x_{4} \leq 1,0052,0,8929 \leq x_{5} \leq 1,7391,0918 \leq x_{6} \leq 1,8519$;

$0,8267 \leq x_{7} \leq 0,9276,0,8543 \leq x_{8} \leq 0,8608$;

$0,2967 \leq x_{9} \leq 0,3208,0,0602 \leq x_{10} \leq 0,1071,0,000 \leq x_{11} \leq 0,1953$;

$0,0291 \leq x_{12} \leq 0,0591,26,9076 \leq x_{13} \leq 42,1939,0,019 \leq x_{14} \leq 0,0588$;

$1,5143 \leq x_{15} \leq 4,5555,43,3698 \leq x_{16} \leq 52,1809,0,4036 \leq x_{17} \leq 0,5356$;

$0,2309 \leq x_{18} \leq 0,3542,0,3102 \leq x_{19} \leq 0,5636,1,0012 \leq x_{20} \leq 1,7343$;

$0,9501 \leq x_{21} \leq 1,5347,2,0088 \leq x_{22} \leq 11,8686,0,3989 \leq x_{23} \leq 0,8124$;

$0,6556 \leq x_{24} \leq 0,7777,0,3486 \leq x_{25} \leq 0,5437,0,2803 \leq x_{26} \leq 0,524$;

$0,4346 \leq x_{27} \leq 0,5834,401596,000 \leq x_{28} \leq 1508005,00,3,053 \leq x_{29} \leq 10,8301$;

$0,4774 \leq x_{30} \leq 0,5951,0,0244 \leq x_{31} \leq 0,0393,0,1998 \leq x_{32} \leq 0,2863$;

$0,0775 \leq x_{33} \leq 0,1111,0,0860 \leq x_{34} \leq 0,1612,0,1792 \leq x_{35} \leq 0,2835$;

$0,1275 \leq x_{36} \leq 0,2886,0,0643 \leq x_{37} \leq 0,2902,1,0865 \leq y_{1} \leq 1,284$;

$1,0537 \leq y_{2} \leq 1,7492 ; 0,8921 \leq y_{3} \leq 2,5947,1000,9625 \leq y_{4} \leq 2556,5671$,

$0,0537 \leq y_{5} \leq 0,7492 ; 0,0324 \leq y_{6} \leq 0,1795,0,2805 \leq y_{7} \leq 0,4784$,

$0,1653 \leq y_{8} \leq 0,3977 ; 0,1043 \leq y_{9} \leq 0,337$. 
Analysis of mathematical methods of solving this type of optimization problems showed the feasibility of using the procedure fminimax that software is implemented in MatLab. The computed optimal values of the export-import potential of the enterprise are:

$$
\begin{aligned}
& x_{1}=0,4671, x_{2}=0,1227, x_{3}=10301,27 ; x_{4}=0,9055, x_{5}=0,8929, \\
& x_{6}=1,0918, x_{7}=0,8267 ; x_{9}=0,2967, x_{10}=0,0602, x_{11}=0,1953 ; x_{12}=0,0291, \\
& x_{13}=26,9076, x_{14}=0,019 ; x_{15}=1,5143, x_{16}=43,3698, x_{17}=0,4036 ; \\
& x_{18}=0,2309, x_{19}=0,3102, x_{20}=1,0012 ; x_{21}=0,9501, x_{22}=2,008, \\
& x_{23}=0,3989 ; x_{24}=0,6556, x_{25}=0,3486, x_{26}=0,2803 ; x_{27}=0,4346, \\
& x_{28}=401596,0, x_{29}=3,053 ; x_{30}=0,4774, x_{31}=0,0244, x_{32}=0,1998 ; \\
& x_{33}=0,0775, x_{34}=0,086, x_{35}=0,1792 ; x_{36}=0,1275, x_{37}=0,0643, y_{1}=1,0865, \\
& y_{2}=1,0537 ; y_{3}=2,5947, y_{4}=1000,963, y_{5}=0,0537 ; y_{6}=0,0324, \\
& y_{7}=0,2805, y_{8}=0,1653 ; y_{9}=0,1043 .
\end{aligned}
$$

The values of individual criteria, namely the maximum level of development of export and import potential of enterprise "Turboatom" are equal 0,4004 $\left(F_{1 \max }=0,4004\right)$, and the maximum level 0,4392 $\left(F_{2 \max }=0,4392\right)$.Comparison of the levels testifies to the great possibilities of the enterprise to use its export and import potential. Therefore, to develop management actions for the use and development of this potential it is necessary to compare these levels with the levels calculated as a convolution of the system of private indicators of specified states of the potential. If you continue this analysis with the construction of a causal diagram factors of increasing the level of export-import potential and its use, it is possible to specify the state of each element and to develop mechanisms to deal with identified problems, as well as set unused opportunities and available reserves.

\section{CONCLUSIONS}

Thus, the modeling of export-import potential should be carried out in a sequence transformation models, namely the cognitive $\rightarrow$ meaningful $\rightarrow$ conceptual $\rightarrow$ information $\rightarrow$ math. This logic provides a scientific, accuracy, adequacy, objectivity in the description and management of this potential.

Proposped models of export and import potential are scientific basis for the formation of effective managerial decisions for using, development, improvement of international business. In terms of enterprise, we offer information and mathematical models may be used in the development of various strategy activities and programmes to improve management efficiency, determination of the reserves development. Based on the results of such modeling provides consistency in the management of export-import potential of the enterprises and other economic objects and provides features to implement a system of digitization in the economy.

\section{REFERENCES}

Draghescu, F. (2015). The Analysis Of Flat Glass Exports For Romania Using The Gravity Model. "Annals of Faculty of Economics", 1(1). 
Cooke, S. \& Watson, P. (2011). A Comparison of Regional Export Enhancement and Import Substitution Economic Development Strategies. "Journal of Regional Analysis and Policy", 41(1).

Introduction to mathematical modeling: Proc. the allowance / Under the editorship of P.V. Trusov. - M.: Logos, 2004.

Kasyanov N.V. (2013). Enterprise Potential: formation and usage. / [N. Kasyanov V., Solokha D.V., Moreva V.V., Belyakov A.V., Be. Balakay A.] 2nd ed. - K.: Type. „Center of educational literature".

Malyarets L. Economic-mathematical methods and models: a tutorial. - Kharkov : Publishing House. KNUE them. S. Kuznets, 2014.

Malyarets L., Barannik I., Zhukov A. (2018). Mathematical tools for monitoring export-import capacity of Ukrainian industrial enterprises. Proceedings of the International Congress on Business and Marketing, Maltepe University, Istanbul, 29.11.2018 - 01.12.2018.

Malyarets L. (2017). Strategic management export-import activities of the company on the principles of controlling [Electronic resource]: monograph / Malyarets L., Otenko I., Morgun G. Electron. text Dan. (3,73 MB). - Kh.: KNUE them. S. Kuznets.

Malyarets, L. (2006). Measurement of features of objects in economy: monograph / Kharkov: Kh.: KNUE them. S. Kuznets.

Minh Quang Dao, M. (2014). Exports, imports, government consumption and economic growth in upper-middle income countries. "Progress in Development Studies", 14(2).

Otenko I. (2015). The Formation mechanism of management of economic potential of the enterprise / Otenko I. // Business inform.

Pogorelov Y.S. (2016), Changes of potential of the enterprise as the driving force of its development / J.S. Pogorelov // Economy and region. - No. 2.

Pralea, S. (2012). References Of The New Theory Of Trade And Economic Growth. "CES Working Papers", 4(4).

Publication of documents of the State Service of Statistics of Ukraine (2019). Retrieved from https://ukrstat.org/uk

Stoian, M., Rialp, A. \& Rialp, J. (2012). International marketing strategy and export performance in Spanish SMEs: a contingency approach. "International Journal of Entrepreneurship and Small Business", Vol. 15(2).

Zdeněk Mikoláš «Potential theory and innovation dynamics of enterprise»

http://cejsh.icm.edu.pl/cejsh/element/bwmeta1.element.desklight-821959dc-2930-4eb8-9e3fa90a7605e242

DOI: $10.7862 /$ rz.2019.mmr.21

The text was submitted to the editorial office: October 2019.

The text was accepted for publication: October 2019. 
